\title{
Neuroprotective effect of an angiotensin receptor type 2 agonist following cerebral ischemia in vitro and in vivo
}

Seyoung Lee ${ }^{1}$, Vanessa H Brait ${ }^{1}$, Thiruma V Arumugam², Megan A Evans ${ }^{1}$, Hyun Ah Kim¹', Robert E Widdop', Grant R Drummond ${ }^{1}$, Christopher G Sobey ${ }^{1 *+}$ and Emma S Jones ${ }^{1+}$

\begin{abstract}
Background: Intracerebral administration of the angiotensin II type 2 receptor ( $A T_{2} R$ ) agonist, CGP42112, is neuroprotective in a rat model of ischemic stroke. To explore further its possible cellular target(s) and therapeutic utility, we firstly examined whether CGP42112 may exert direct protective effects on primary neurons following glucose deprivation in vitro. Secondly, we tested whether CGP42112 is effective when administered systemically in a mouse model of cerebral ischemia.

Methods: Primary cortical neurons were cultured from E17 C57Bl6 mouse embryos for $9 \mathrm{~d}$, exposed to glucose deprivation for $24 \mathrm{~h}$ alone or with drug treatments, and percent cell survival assessed using trypan blue exclusion. Ischemic stroke was induced in adult male C57Bl6 mice by middle cerebral artery occlusion for 30 min, followed by reperfusion for $23.5 \mathrm{~h}$. Neurological assessment was performed and then mice were euthanized and infarct and edema volume were analysed.

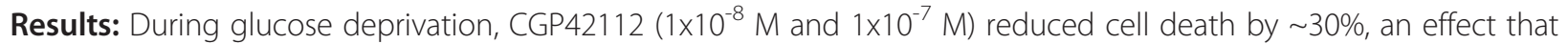
was prevented by the $\mathrm{AT}_{2} \mathrm{R}$ antagonist, PD123319 $\left(1 \times 10^{-6} \mathrm{M}\right)$. Neuroprotection by CGP42112 was lost at a higher concentration $\left(1 \times 10^{-6} \mathrm{M}\right)$ but was unmasked by co-application with the $A T_{1} R$ antagonist, candesartan $\left(1 \times 10^{-7} \mathrm{M}\right)$. By contrast, Compound $21\left(1 \times 10^{-8} \mathrm{M}\right.$ to $\left.1 \times 10^{-6} \mathrm{M}\right)$, a second $A T_{2} R$ agonist, had no effect on neuronal survival. Mice treated with CGP42112 (1 mg/kg i.p.) after cerebral ischemia had improved functional outcomes over vehicle-treated mice as well as reduced total and cortical infarct volumes.
\end{abstract}

Conclusions: These results indicate that CGP42112 can directly protect neurons from ischemia-like injury in vitro via activation of $A T_{2} R s$, an effect opposed by $A T_{1} R$ activation at high concentrations. Furthermore, systemic administration of CGP42112 can reduce functional deficits and infarct volume following cerebral ischemia in vivo.

Keywords: Apoptosis, AT2 receptor, Cerebral ischemia, Glucose deprivation, Mouse, Neuronal death, Neuroprotection, Stroke

\section{Introduction}

Stroke is the world's second most common cause of death and a leading cause of long-term disability in adults [1]. Currently, there are very few safe and effective treatment options available for patients following stroke [2] and hence there is a great need to develop new therapies that may improve stroke outcome. It is conceivable

\footnotetext{
* Correspondence: chris.sobey@monash.edu

tEqual contributors

'Department of Pharmacology, Monash University, Clayton, VIC 3800,

Australia

Full list of author information is available at the end of the article
}

that targeting elements of the renin-angiotensin system (RAS) may provide neuroprotection prior to and/or following stroke [3-11].

The major peptide of the RAS is angiotensin II (Ang II), which acts with equal affinity at two membranebound receptors, the angiotensin type 1 receptor $\left(A_{1} R\right)$ and the type 2 receptor $\left(\mathrm{AT}_{2} \mathrm{R}\right)$. It is well established that excessive stimulation of the $\mathrm{AT}_{1} \mathrm{R}$ by Ang II mediates biologically detrimental actions in the setting of cerebrovascular disease [3,12-14], whereas activation of the $\mathrm{AT}_{2} \mathrm{R}$ may at least partly offset the effects of $\mathrm{AT}_{1} \mathrm{R}$

\section{Ciomed Central}


stimulation and is associated with a protective function [15]. In addition, blockade of the $\mathrm{AT}_{1} \mathrm{R}$ may be protective at least in part because it results in greater binding to and activation of the $\mathrm{AT}_{2} \mathrm{R}$ by Ang II [3-5]. A number of clinical trials have demonstrated the beneficial effects of sartan class drugs $\left(\mathrm{AT}_{1} \mathrm{R}\right.$ antagonists) such as candesartan and eprosartan, given prior to and following stroke $[16,17]$.

The $\mathrm{AT}_{2} \mathrm{R}$ is the predominant angiotensin receptor subtype expressed in fetal organs, and its expression is downregulated following birth $[9,18]$. Interestingly, recent studies have shown that under pathological conditions such as ischemic insult, $\mathrm{AT}_{2} \mathrm{R}$ expression may be upregulated $[7,9]$ and it may play an important role in the growth, repair and regeneration of neuronal tissue.

To date only one study has tested for a neuroprotective effect of direct $\mathrm{AT}_{2} \mathrm{R}$ activation using a selective $\mathrm{AT}_{2} \mathrm{R}$ agonist in the setting of stroke, and it suggested that direct $\mathrm{AT}_{2} \mathrm{R}$ activation is beneficial during ischemic stroke in spontaneously hypertensive rats subjected to cerebral ischemia [8]. Specifically, intracerebral administration of the $\mathrm{AT}_{2} \mathrm{R}$ agonist, CGP42112, prior to ischemia resulted in a reduced infarct volume at $72 \mathrm{~h}$ [8]. This protective effect of CGP42112 was abolished by administration of PD123319 (an $\mathrm{AT}_{2} \mathrm{R}$ antagonist), confirming a role for $\mathrm{AT}_{2} \mathrm{R}$. In the brain, $\mathrm{AT}_{2} \mathrm{Rs}$ are known to be expressed in neurons [7] and also in vascular cells [5], although the target cell types for the protective action of CGP42112 remain unknown.

In the present study, we firstly tested the hypothesis that selective $\mathrm{AT}_{2} \mathrm{R}$ activation is directly neuroprotective in vitro using primary cortical neuron cultures deprived of glucose. Secondly, we tested whether CGP42112 may be effective in limiting neurological deficit when administered systemically following cerebral ischemia in a mouse model of stroke.

\section{Materials and methods \\ Animals}

All animal experiments were performed in accordance with the National Health and Medical Research Council of Australia guidelines, and with approval from the Monash University Animal Ethics Committee (Projects SOBSB/2010/34 and SOBSB/2009/55). Thirteen pregnant C57BL6/J (Monash Animal Research Platform) females were used to obtain cortical neurons from E17 pups. For cerebral ischemia-reperfusion (I/R) experiments in vivo, we used a total of 40 male C57BL/6 mice (8-12 weeks old; weight $=26 \pm 6 \mathrm{~g})$. Five mice were excluded from the study when, during the surgical procedure to induce cerebral ischemia-reperfusion: (1) there was inadequate $(<70 \%)$ reduction in regional cerebral blood flow $(\mathrm{rCBF})(\mathrm{n}=2)$; or $(2)$ no measured increase in blood flow at reperfusion after $30 \mathrm{~min}$ ischemia $(\mathrm{n}=1)$; or (3) animals died before $24 \mathrm{~h}$ of reperfusion had elapsed $(n=2)$.

\section{Primary neuronal cultures}

Mouse primary cortical neurons were prepared as previously described [19] with some modifications. Timed pregnant mice were anesthetized using inhaled isoflurane and an incision was made in the abdominal wall to remove embryos, which were immediately placed and dissected in Hank's balanced salt solution (HBSS) (Invitrogen, Melbourne) without $\mathrm{Ca}^{2+}$ and $\mathrm{Mg}^{2+}$, supplemented with HEPES (10 mmol/L) (Invitrogen, Melbourne), gentamicin $(5 \mathrm{mg} / \mathrm{L})$ (Invitrogen, Melbourne). Dissected cortices (free of meninges) were digested in trypsin (1 $\mathrm{mg} / \mathrm{ml}$ ) (Sigma, Sydney) for $10 \mathrm{~min}$ at room temperature, neutralized with trypsin inhibitor (Sigma, Sydney) for $10 \mathrm{~min}$, and washed three times with Neurobasal medium (NBM) (Invitrogen, Melbourne) supplemented with L-glutamine $(2 \mathrm{mmol} / \mathrm{L})$, gentamycin (5 $\mathrm{mg} / \mathrm{L}$ ), and B-27 supplements (Invitrogen, Melbourne) $\mathrm{pH}$ 7.2. Dissociated cell suspensions were resuspended in NBM (+ supplements) then dispensed into poly-Dlysine (Sigma, Sydney) coated $60-\mathrm{mm}^{2}$ Petri dishes. Cells were incubated overnight at $37{ }^{\circ} \mathrm{C}$ in a humidified atmosphere of $5 \% \mathrm{CO}_{2}$ in air. Medium was replaced with fresh NBM (+ supplements), and the cells were maintained for a further $8 \mathrm{~d}$ without renewal of the medium.

\section{Glucose deprivation}

Glucose deprivation was used to induce slow cell death through apoptotic mechanisms, analogous to the postischemic neuronal death that occurs in the penumbra region surrounding an infarct core in vivo [20-22]. For glucose deprivation, cultured neurons ( $9 \mathrm{~d}$ in vitro) were incubated in glucose-free Locke's medium containing (in $\mathrm{mmol} / \mathrm{L}) \mathrm{NaCl}$ 154.0, $\mathrm{KCl}$ 5.6, $\mathrm{CaCl}_{2} 2 \mathrm{H}_{2} \mathrm{O}$ 2.3, $\mathrm{MgCl}_{2} 6 \mathrm{H}_{2} \mathrm{O}$ 1.0, $\mathrm{NaHCO}_{3}$ 3.6, HEPES 5.0, pH 7.2, supplemented with gentamicin $(5 \mathrm{mg} / \mathrm{L})$ at $37{ }^{\circ} \mathrm{C}$ in a humidified atmosphere of $5 \% \mathrm{CO}_{2}$ in air for $24 \mathrm{~h}$. For drug treatments, cells were exposed to one or more of the following: CGP42112 $\left(1 \times 10^{-8}, 1 \times 10^{-7}\right.$ or $1 \times 10^{-6} \mathrm{M}$; GLS

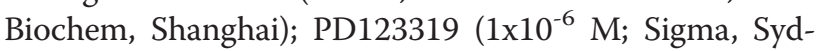
ney); Compound $21\left(1 \times 10^{-8}, 1 \times 10^{-7}\right.$ or $1 \times 10^{-6} \mathrm{M}$; kindly provided by A. Hallberg, Department of Medicinal Chemistry, Uppsala University, Sweden); or candesartan $\left(1 \times 10^{-7} \mathrm{M}\right.$; Astrazeneca, Sweden). All drugs were dissolved and diluted in distilled water.

\section{Cell viability assay}

Cell viability was determined by trypan blue exclusion. In brief, cells were incubated at $37^{\circ} \mathrm{C}$ in $0.2 \%$ trypan blue for $15 \mathrm{~min}$. After washing three times with phosphate buffered saline (PBS; $\mathrm{pH} 7.4$ ), cells were fixed with $4 \%$ paraformaldehyde for $10 \mathrm{~min}$. Twenty images of random 


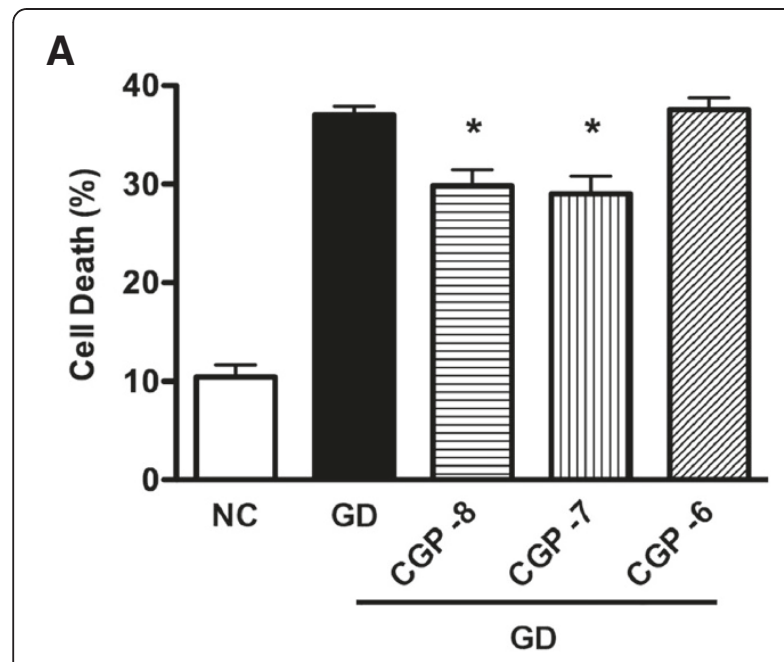

B

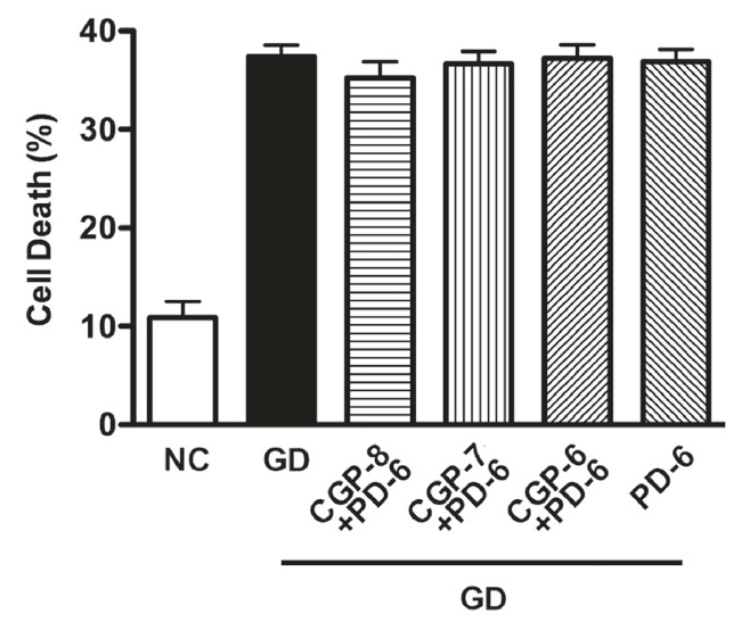

C

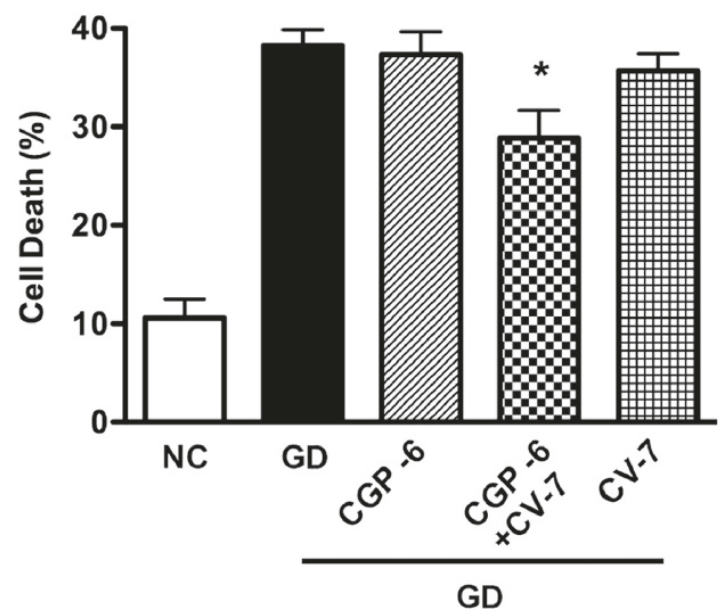

Figure 1 Mean percentage neuronal cell death. A. Data are shown for cells exposed to normal conditions (NC) or glucose deprivation with vehicle for $24 \mathrm{~h}(\mathrm{GD})$. Other cells exposed to GD were treated with CGP42112 at $1 \times 10^{-8} \mathrm{M}(\mathrm{CGP}-8), 1 \times 10^{-7} \mathrm{M}(\mathrm{CGP}-7)$, $1 \times 10^{-6} \mathrm{M}(\mathrm{CGP}-6)(\mathrm{n}=8)\left({ }^{*} P<0.05\right.$ vs. NC). B. Data are shown for cells exposed to normal conditions (i.e. $24 \mathrm{~h} \mathrm{NC}$ ) or glucose deprivation with vehicle (24 h GD) or 3 concentrations of CGP42112 in the presence of PD123319 at $1 \times 10^{-6} \mathrm{M}$ (PD-6). Data for GD with PD123319 alone $(n=6)$ are also shown $\left({ }^{*} P<0.05\right.$ vs. vehicle; NS $P>0.05$ vs. vehicle). C. Data are shown for cells exposed to normal conditions (NC) or glucose deprivation (GD) with vehicle (24 h GD) or $1 \times 10^{-6}$ M CGP42112 (CGP-6) in the absence or presence of $1 \times 10^{-7} M$ candesartan $(C V-7)\left(n=7 ;{ }^{*} P<0.05\right.$ vs. vehicle).

fields at 200 magnification were taken from each dish using an inverted microscope and camera (Nikon, Japan) and associated computer software NIS-elements version 3.0 (Nikon, Japan). Approximately one thousand cells were counted from each dish. Cell viability was determined based on colour, size and cellular morphology by an experimenter blinded to the treatment group, and the cell death occurring during the $24 \mathrm{~h}$ glucose deprivation period was calculated.

\section{Cerebral ischemia-reperfusion in vivo}

We used a model of focal cerebral ischemia-reperfusion similar to that described previously [23,24]. Briefly, mice were anesthetized with a mixture of ketamine $(80 \mathrm{mg} / \mathrm{kg}$ i.p.) and xylazine $(10 \mathrm{mg} / \mathrm{kg}$ i.p.). A midline neck incision was made, and the right external carotid (ECA) and pterygopalatine arteries were isolated and cauterized. The internal carotid artery (ICA) was lifted and occluded at the peripheral site of the bifurcation of the ICA. Focal cerebral ischemia was induced by intraluminal filament occlusion for $30 \mathrm{~min}$ of the right middle cerebral artery (MCA) with a 6-0 nylon monofilament with a siliconecoated tip (0.20-0.22 mm, Doccol Co., Redlands, CA, USA). Severe ( $75 \%)$ reduction in rCBF was confirmed using trans-cranial laser-Doppler flowmetry (Perimed) in the area of cerebral cortex supplied by the MCA ( 2 $\mathrm{mm}$ posterior and $\sim 5 \mathrm{~mm}$ lateral to bregma). Mice were treated i.p. with either vehicle (saline; $\mathrm{n}=16$ ) or CGP42112 $(1 \mathrm{mg} / \mathrm{kg} ; \mathrm{n}=19)$ at the commencement of reperfusion.

\section{Neurological assessment and quantification of infarct volume}

Neurological deficit was evaluated using a five-point scoring system ( 0 , no deficit; 1 , failure to extend right paw; 2, circling to the right; 3 , falling to the right; and 4, unable to walk spontaneously) and hanging wire test in a blinded fashion, as described previously [23-26]. Briefly, mice were suspended from a $30 \mathrm{~cm}$ high wire by their forelimbs for up to $60 \mathrm{~s}$. Average hanging time (i.e. 


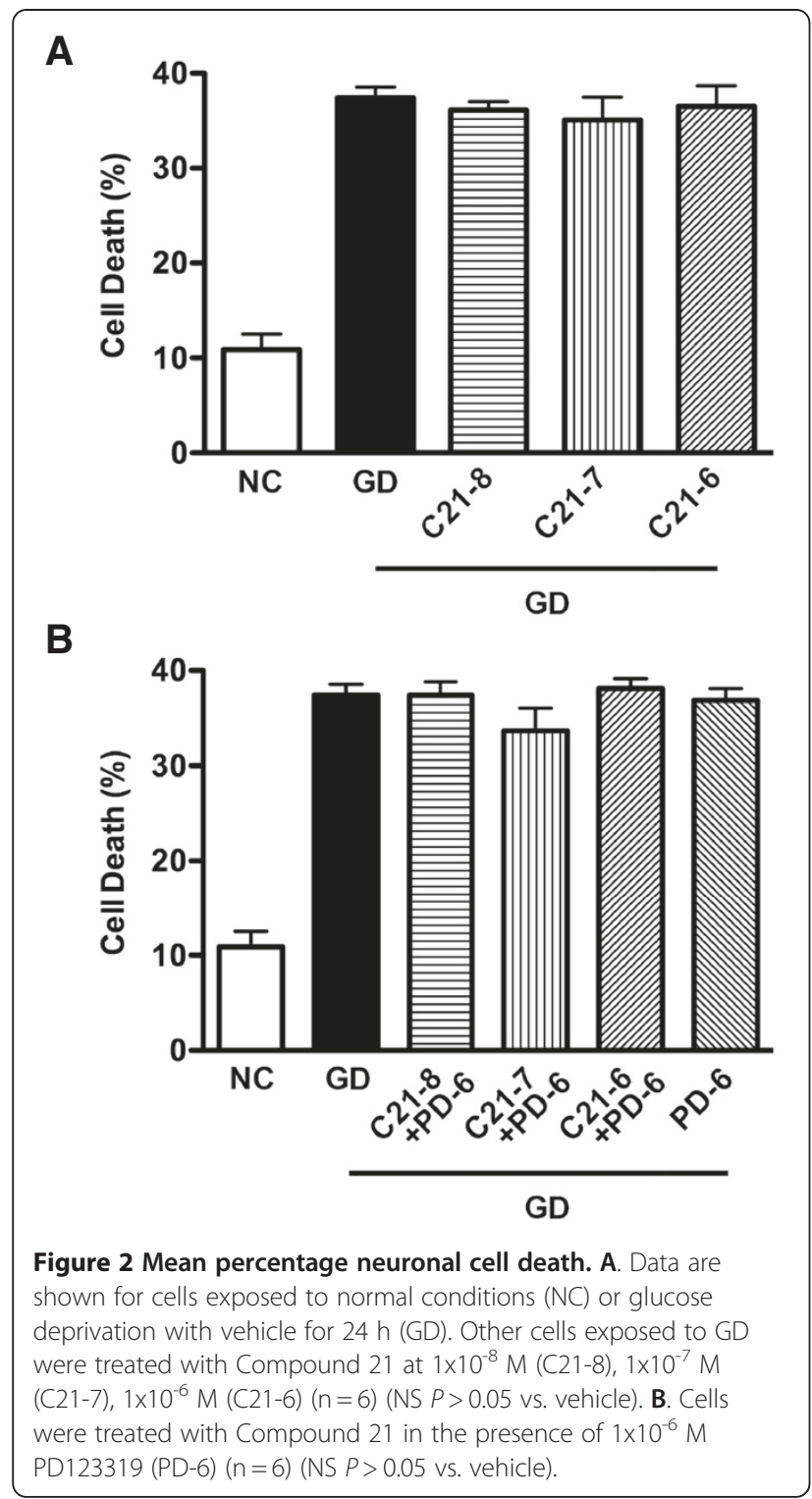

latency to fall) of 3 trials with 5 min rest in between was recorded. Cerebral infarct distribution and volumes of infarct and edema were also estimated as described previously $[23,24]$.

\section{Double-label fluorescent immunohistochemistry}

Serial coronal sections ( $10 \mu \mathrm{m}$ thick) were collected for analysis. Brain sections were fixed in acetone for $15 \mathrm{~min}$ and washed in $0.01 \mathrm{M}$ phosphate-buffered saline (PBS, $3 \times 10 \mathrm{~min})$. Sections were blocked with $10 \%$ goat serum (Abcam) for $30 \mathrm{~min}$ then incubated overnight in antirabbit active Caspase 3 (1:200; Abcam) and anti-mouse NeuN (1:1000; Chemicon). Following several washes in PBS (3 x $10 \mathrm{~min})$, sections were incubated with Alexa 594-conjugated anti-rabbit IgG (1:500; invitrogen) for $2 \mathrm{~h}$ in room temperature. Brain sections were then washed with PBS ( $3 \times 5 \mathrm{~min})$ and incubated in M.O.M Biotinylated anti-mouse IgG Reagent (Vector Laboratories) for $10 \mathrm{~min}$. Sections were then again washed in PBS $(2 \times 2$ min) and Fluorescein Avidin DCS (Vector Laboratories)

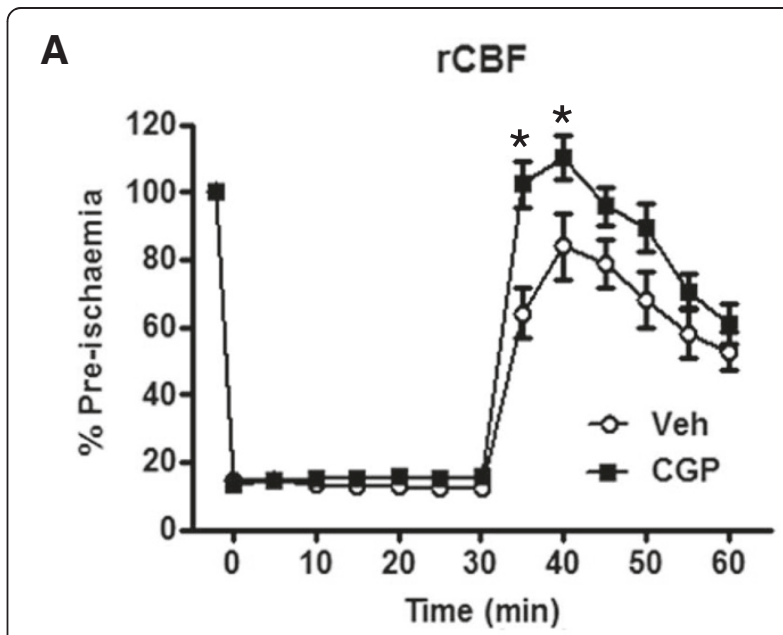

B
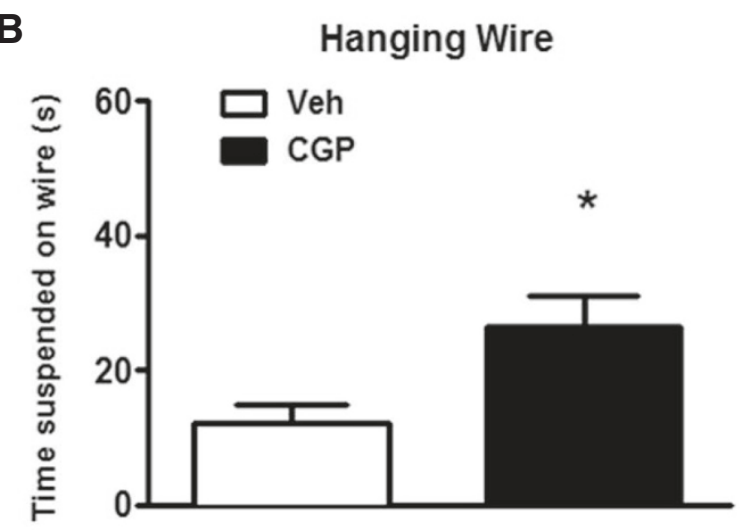

C

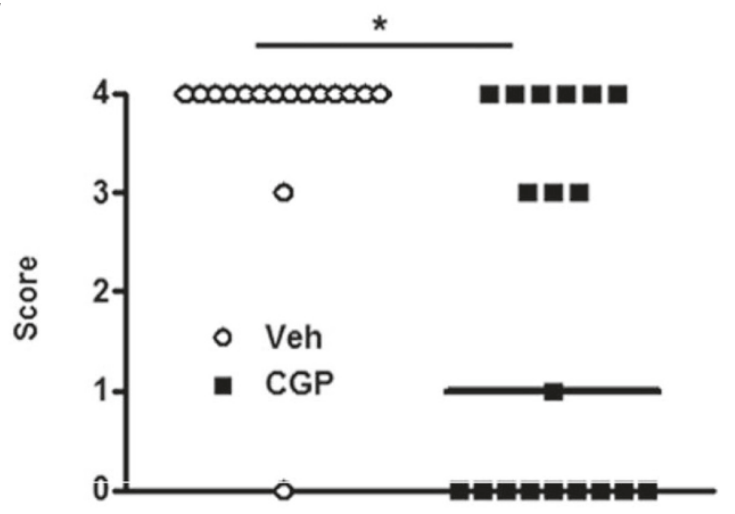

Figure 3 Regional cerebral blood flow (rCBF) and neurological function in vehicle- and CGP42112-treated mice. Data for rCBF $(\mathbf{A})$, neurological deficit score (B) and hanging-wire test (C) are shown for animals $24 \mathrm{~h}$ following cerebral ischemia and treatment with either vehicle (Veh; $n=16)$ or CGP42112 $\left(n=19 ;{ }^{*} P<0.05\right.$ vs. vehicle) 
was applied for $5 \mathrm{~min}$. Sections were washed in PBS $(3 \mathrm{x}$ $10 \mathrm{~min}$ ) and cover-slipped. Staining was analysed on an Olympus fluorescence/light microscope (Olympus, Hamburg, Germany).

\section{Data analysis}

Results are reported as the mean \pm standard error (SEM). Statistical differences $(\mathrm{P}<0.05)$ were determined by oneway analysis of variance (ANOVA) with Dunnett's posthoc test or an unpaired $t$-test, as appropriate, using GraphPad Prism version 5 (Graph Pad Software Inc., San Diego, CA).

\section{Results}

\section{Effects of $A T_{2} R$ agonists on death of primary cortical} neurons during glucose deprivation

Following exposure of primary cortical neurons to $24 \mathrm{~h}$ of glucose deprivation, cell death was markedly enhanced ( 35-40\%; see Figures 1, 2, 3). Treatment with the $\mathrm{AT}_{2} \mathrm{R}$ agonist CGP42112 $\left(1 \times 10^{-8}\right.$ or $\left.1 \times 10^{-7} \mathrm{M}\right)$ resulted in a $\sim 30 \%$ reduction in cell death due to glucose deprivation, whereas a higher concentration of CGP42112 (1x10 $\mathrm{M})$ had no protective effect (Figure 1A). The protection by $1 \times 10^{-8} \mathrm{M}$ and $1 \times 10^{-7} \mathrm{M}$ CGP42112 was prevented by co-treatment with the

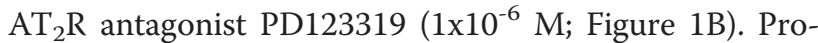
tection by $1 \times 10^{-6}$ M CGP42112 was unmasked by cotreatment with the $\mathrm{AT}_{1} \mathrm{R}$ antagonist candesartan $\left(1 \times 10^{-7}\right.$ M; Figure 1C). In contrast to the effect of CGP42112, the putative $\mathrm{AT}_{2} \mathrm{R}$ agonist Compound $21\left(1 \times 10^{-8}\right.$ to $1 \times 10^{-6} \mathrm{M}$ ) exerted no effects on cell death induced by glucose deprivation (Figure 2A-B).

\section{Effect of systemic administration of CGP42112 on outcome following ischemic stroke}

Vehicle or CGP42112 was injected at the time of reperfusion in all mice. Cerebral blood flow profiles were similar between the two groups of mice during the 30 min of middle cerebral artery occlusion and by the end of the $30 \mathrm{~min}$ recording period following reperfusion (Figure 3A). However, compared with vehicle treatment, blood flow was transiently but significantly higher in CGP42112-treated mice during the first $10 \mathrm{~min}$ of reperfusion (Figure 3A). Mice treated with CGP42112 also exhibited a significant improvement in functional outcomes at $24 \mathrm{~h}$ as measured using a neurological deficit score and by hanging wire time (Figure 3B-C). In addition, total and cortical infarct volumes in mice treated with CGP42112 were significantly reduced compared with vehicle-treated mice. (Figures 4 and 5). Edema

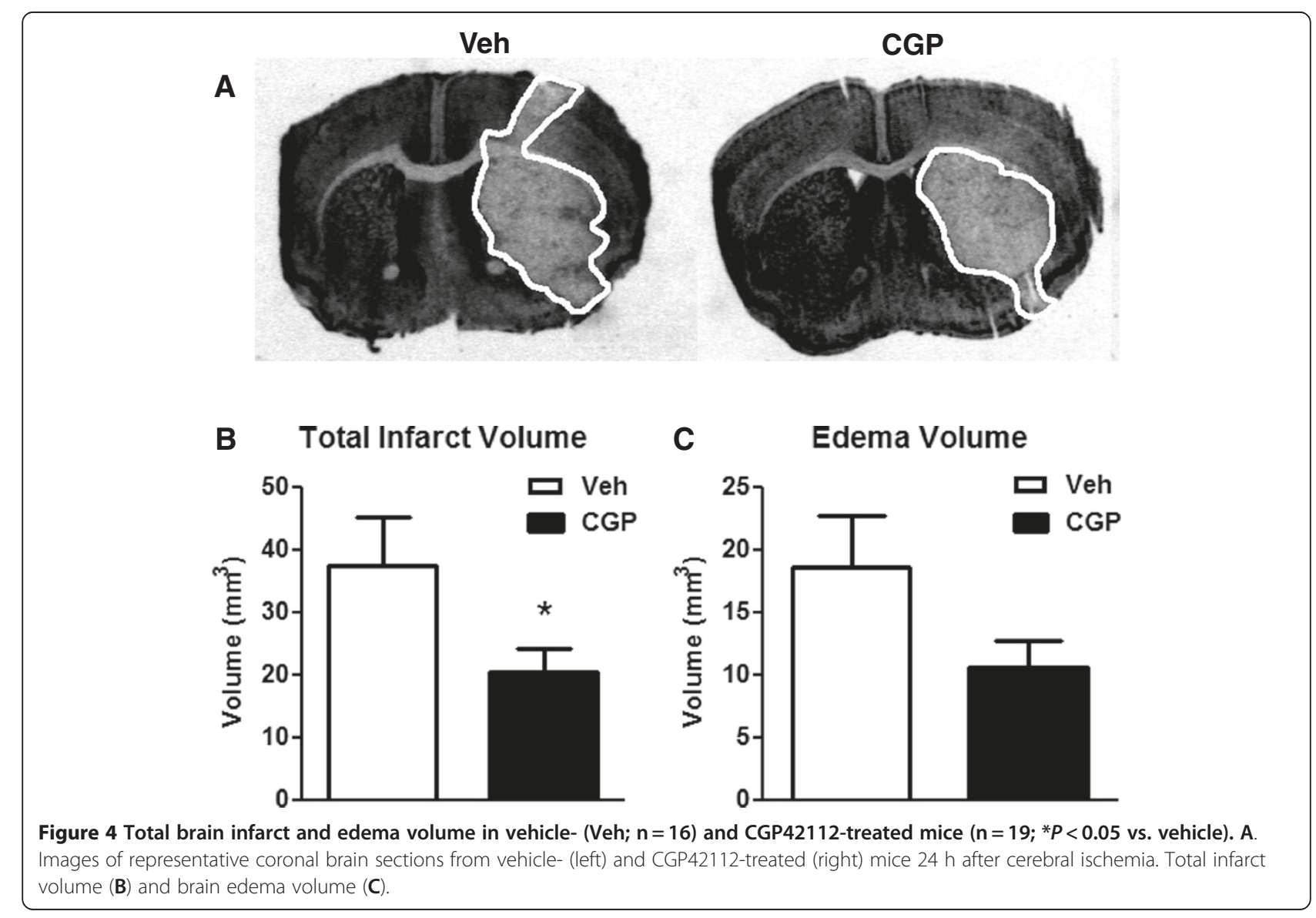




\section{A Cortical Infarct Volume}

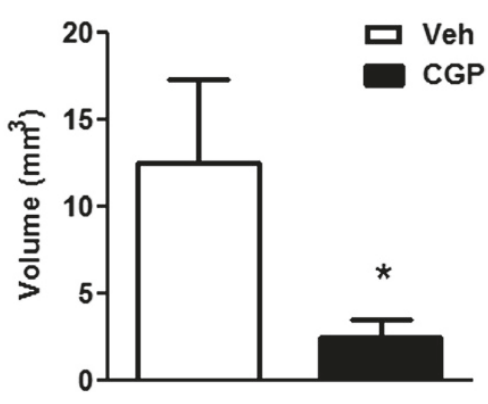

\section{Subcortical Infarct Volume}

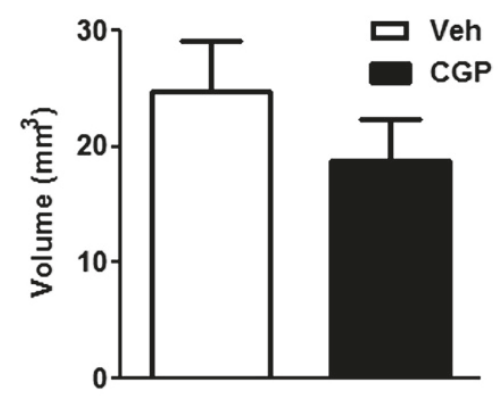

B

\section{Cortical Infarct Distribution}

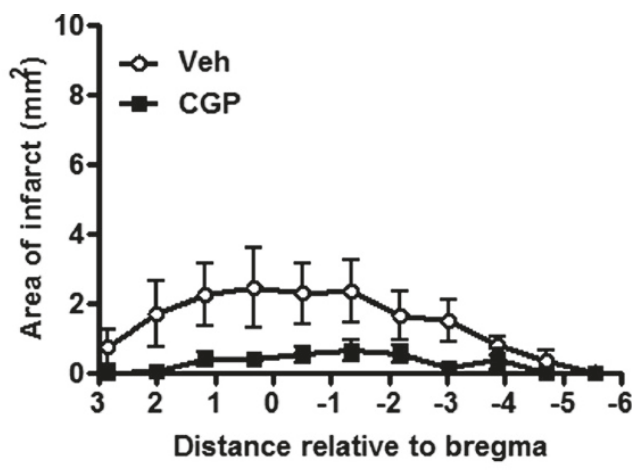

D Subcortical Infarct Distribution

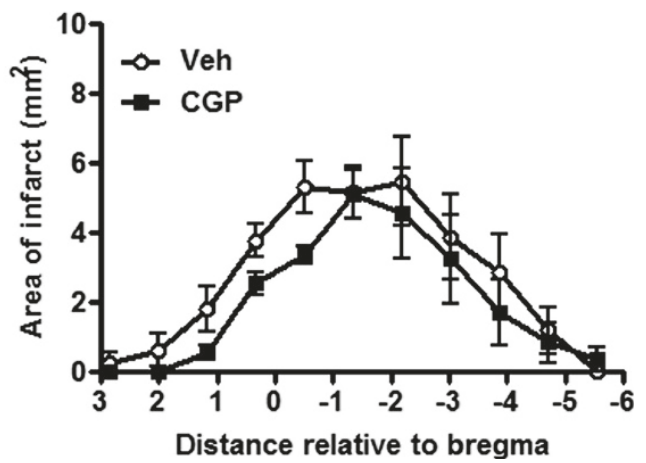

Figure 5 Cortical (A-B) and subcortical (C-D) brain infarct volume and distribution in vehicle- (Veh; $n=16)$ and CGP42112-treated mice $\left(\mathrm{n}=19 ;{ }^{*} P<0.05\right.$ vs. vehicle).

volume also tended to be smaller in CGP42112- than vehicle-treated mice (Figure 4D).

\section{Effect of CGP42112 on neuronal apoptosis in vivo}

Finally, we performed a small number of studies (4 vehicle-treated and 4 CGP42112-treated mice) to assess whether the neuroprotective effects of CGP42112 following stroke may be associated with attenuated neuronal apoptosis in vivo. For this, we utilised doublelabelling immunohistochemistry for cells staining positive for cleaved/activated caspase 3 and NeuN (the neuronal marker). In each mouse brain, we counted between 600 and 3600 cells in 9 sections of somatosensory cortex (bregma +1.18 to $-2.18 \mathrm{~mm}$ ) at $200 x$ magnification. Cleaved/activated Caspase 3 immunoreactivity was present in at least some sections from each of the vehicle-treated mice, at a frequency of $3.43 \pm 1.03 \%$ of the 6,154 NeuN-positive cells counted. By contrast, no immunoreactivity for cleaved caspase 3 was detectable in any of the 36 sections, containing 5,709 NeuN-positive cells counted from CGP42112-treated mice (i.e. $0.00 \pm 0.00 \% ; \mathrm{p}=0.06$ versus vehicle, $\mathrm{n}=4$, Wilcoxon signed rank test, GraphPad Prism). These preliminary data suggest that the post-stroke protection afforded by CGP42112 in vivo is associated with reduced neuronal apoptosis.

\section{Discussion}

There are three new major findings of the present study. First, CGP42112, an $\mathrm{AT}_{2} \mathrm{R}$ agonist, exerts direct protective effects on primary neurons in culture to reduce cell death following exposure to glucose deprivation, an effect which was blocked by an $\mathrm{AT}_{2} \mathrm{R}$ antagonist, PD123319. Second, at a high concentration of CGP42112 $\left(1 \times 10^{-6} \mathrm{M}\right)$, its protective effects are lost due to additional activation of $\mathrm{AT}_{1} \mathrm{R}$, and this effect can be prevented with the $\mathrm{AT}_{1} \mathrm{R}$ antagonist, candesartan. Third, systemic administration of CGP42112 at the time of reperfusion following cerebral ischemia in mice results in substantially less neurological deficit and infarct volume at $24 \mathrm{~h}$. Together, these results suggest that the neuronal $\mathrm{AT}_{2} \mathrm{R}$ is a valid therapeutic target for treatment following ischemic stroke and that CGP42112 can be 
administered systemically following stroke to bring about functional benefits.

We have previously reported that pretreatment with CGP42112 can limit infarct volume following cerebral ischemia in spontaneously hypertensive rats when injected intracerebrally into the region to be subjected to ischemia [8]. It is unknown what cell type(s) might be the target for such protective effects of CGP42112 in vivo. The use of primary neuronal cultures in this study has thus enabled us to evaluate whether CGP42112 might potentially have a direct protective effect on neurons subjected to ischemia-like conditions. Indeed, we found that this $\mathrm{AT}_{2} \mathrm{R}$ agonist (at $1 \times 10^{-8} \mathrm{M}$ and $1 \times 10^{-7} \mathrm{M}$ ) can modestly protect neurons from such cell death. Our findings are analogous to those of $\mathrm{Li}$ et al. (2005) [7] whereby $\mathrm{AT}_{2} \mathrm{R}$ stimulation with Ang II significantly increased viability of cultured neurons subjected to glutamate-induced neuronal injury.

Interestingly, the neuroprotective effect of CGP42112 was lost at the highest concentration tested (i.e. $1 \times 10^{-6}$ $\mathrm{M})$. Incomplete selectivity of CGP42112 for the $\mathrm{AT}_{2} \mathrm{R}$ over the $\mathrm{AT}_{1} \mathrm{R}$ has been noted at high concentrations [27]. There is good evidence that activation of the $A_{1} R$ may contribute to the pathology of stroke [15], as well as glutamate-induced neuronal injury [7]. We found evidence that the activation of neuronal $\mathrm{AT}_{1} \mathrm{R}$ by $1 \times 10^{-6} \mathrm{M}$ CGP42112 overides its $\mathrm{AT}_{2} \mathrm{R}$-dependent neuroprotection, in that this high concentration of CGP42112 was protective if co-administered with the $\mathrm{AT}_{1} \mathrm{R}$ antagonist, candesartan. Such data support the notion that therapeutic effectiveness of $\mathrm{AT}_{2} \mathrm{R}$ agonists may be greater when co-administered with an $\mathrm{AT}_{1} \mathrm{R}$ antagonist [15].

Unlike CGP42112, we found no evidence for any protective effect by a similar range of concentrations of Compound 21. This drug, which is reported to be an orally active non-peptidic $\mathrm{AT}_{2} \mathrm{R}$ agonist, has been shown to have $\sim 10$-fold lower affinity than CGP42112 at the $\mathrm{AT}_{2} \mathrm{R}$ [28]. It is therefore possible that higher concentrations may have been required in the present study to sufficiently activate $\mathrm{AT}_{2} \mathrm{R}$ to provide protection.

Systemic administration of CGP42112, commencing at reperfusion, resulted in a markedly improved functional outcome and reduced infarct volume, particularly in the cortical region at $24 \mathrm{~h}$ following transient cerebral ischemia in mice. This finding is analogous to the abovementioned study of McCarthy et al. who found that intracerebral injection of CGP42112 prior to cerebral ischemia exerted neuroprotective effects in the cortex [8]. The fact that systemic administration of CGP42112 achieved significant functional benefits associated with reductions in infarct volume and neuronal apoptosis suggests that movement of the drug across the bloodbrain barrier was effective. Thus, the present work advances the concept that administration of an $\mathrm{AT}_{2} \mathrm{R}$ agonist at the time of tissue plasminogen activatorinduced reperfusion is plausible as a combination treatment in stroke patients with successful post-ischemic reperfusion therapy. Further studies are required to test whether an $\mathrm{AT}_{2} \mathrm{R}$ agonist might also be protective following permanent cerebral ischemia (i.e. without reperfusion). Interestingly, CGP42112 treatment had no significant effect on infarct at subcortical regions or edema volumes at $24 \mathrm{~h}$. It is possible that the clear beneficial effects of CGP42112 on functional outcome measures include facilitation of neuronal activity [7,29] as well as simply preventing neuronal death. Future studies to clarify the extent of protection by CGP42112 treatment at later timepoints and also at different doses are warranted.

While our results suggest that $\mathrm{AT}_{2} \mathrm{R}$ located on neurons could mediate protective effects of CGP42112 in ischemia-like conditions, there are a number of other cell types which may participate in the $\mathrm{AT}_{2} \mathrm{R}$-mediated neuroprotection observed in vivo. In particular, the $\mathrm{AT}_{2} \mathrm{R}$ located on endothelial cells could play an important role in $\mathrm{AT}_{2} \mathrm{R}$-mediated neuroprotection following stroke by supporting cerebral blood flow via endothelium-dependent vasodilatation [30]. Consistent with this possibility, we found that blood flow velocity in the cortical region impacted by cerebral artery occlusion was transiently higher early during reperfusion in animals treated with CGP42112. It remains to be determined whether non-neuronal brain cells, such as astrocytes and oligodendrocytes, might also express $\mathrm{AT}_{2} \mathrm{R}$ that contribute to improved functional outcome following CGP42112 treatment [31]. Furthermore, Iwanami et al. (2011) have recently demonstrated that $\mathrm{AT}_{2} \mathrm{R}$ located on haematopoietic cells may be a target for achieving neuroprotection following stroke [6]. Elucidating the contribution of multiple cell types involved in $\mathrm{AT}_{2} \mathrm{R}$-mediated neuroprotection would aid in a better understanding of the neuroprotective potential of $\mathrm{AT}_{2} \mathrm{R}$ agonists in vivo.

It is important to note that we cannot fully exclude the possibility that infarct volume was still not fully developed at $24 \mathrm{~h}$ in this study, and thus it is possible that the protective effect of CGP42112 after stroke in vivo represented a delay in injury development rather than a complete prevention of it. While we have previously found that infarct volume is no greater at $72 \mathrm{~h}$ than at $24 \mathrm{~h}$ after $30 \mathrm{~min}$ of middle cerebral artery occlusion in C57Bl6 mice [23], a definitive conclusion regarding the sustained protection by CGP42112 cannot be made without a longer timepoint being studied.

In summary, the present study provides evidence that $\mathrm{AT}_{2} \mathrm{R}$ activation by the agonist CGP42112 can both directly protect against neuronal cell death following 
glucose deprivation in vitro, and improve functional outcomes in association with reduced infarct volume when administered systemically following cerebral ischemiareperfusion in vivo. Overall, the findings support the hypothesis that administration of an $\mathrm{AT}_{2} \mathrm{R}$ agonist could be a useful adjunct in the clinical treatment of acute stroke.

\section{Abbreviations}

Ang II: Angiotensin II; AT R R: Angiotensin type 1 receptor; $A T_{2} R$ : Angiotensin type 2 receptor; MCA: Middle cerebral artery; RAS: Renin-angiotensin system; ECA: External carotid artery; ICA: Internal carotid artery; rCBF: Regional cerebral blood flow.

\section{Competing interests}

The authors declare that they have no competing interest.

\section{Authors' contributions}

SL performed animal and cell culture experiments, data analysis and contributed to writing the manuscript. VHB and HK performed animal experiments. MAE performed data analysis. TVA, GRD, REW, ESJ and CGS designed the study, helped to interpret data and contributed to the manuscript. All authors read and approved the final manuscript.

\section{Acknowledgements}

These studies were supported by funds from Project Grants from the National Health and Medical Research Council of Australia (NHMRC) (APP1010984; APP1007986), and a Grant-in-aid from the Heart Foundation of Australia (G 10M 5218). VHB was supported by a Monash Graduate Scholarship. TVA is a Future Fellow of the Australian Research Council. GRD and CGS are Senior Research Fellows of the NHMRC.

\section{Author details}

'Department of Pharmacology, Monash University, Clayton, VIC 3800, Australia. ${ }^{2}$ School of Biomedical Sciences, The University of Queensland, Brisbane, QLD 4072, Australia.

Received: 30 May 2012 Accepted: 15 August 2012 Published: 24 August 2012

\section{References}

1. Zaleska MM, Mercado ML, Chavez J, Feuerstein GZ, Pangalos MN, Wood A: The development of stroke therapeutics: promising mechanisms and translational challenges. Neuropharmacology 2009, 56:329-341.

2. Rahman RMA, Nair SM, Appleton I: Current and future pharmacological interventions for the acute treatment of ischaemic stroke. Current Anaesthesia \& Critical Care 2005, 16:99-109.

3. Dai WJ, Funk A, Herdegen T, Unger T, Culman J: Blockade of central angiotensin AT(1) receptors improves neurological outcome and reduces expression of AP-1 transcription factors after focal brain ischemia in rats. Stroke 1999, 30:2391-2398. discussion 2398-2399.

4. Ito T, Yamakawa H, Bregonzio C, Terron JA, Falcon-Neri A, Saavedra JM: Protection against ischemia and improvement of cerebral blood flow in genetically hypertensive rats by chronic pretreatment with an angiotensin II AT1 antagonist. Stroke 2002, 33:2297-2303.

5. Iwai M, Liu HW, Chen R, Ide A, Okamoto S, Hata R, Sakanaka M, Shiuchi T, Horiuchi M: Possible inhibition of focal cerebral ischemia by angiotensin II type 2 receptor stimulation. Circulation 2004, 110:843-848.

6. Iwanami J, Mogi M, Tsukuda K, Min LJ, Sakata A, Jing F, Ohshima K, Horiuchi M: Effect of angiotensin II type 2 receptor deletion in hematopoietic cells on brain ischemia-reperfusion injury. Hypertension 2011, 58:404-409.

7. Li J, Culman J, Hortnagl H, Zhao Y, Gerova N, Timm M, Blume A, Zimmermann M, Seidel K, Dirnagl U, Unger T: Angiotensin AT2 receptor protects against cerebral ischemia-induced neuronal injury. FASEB J 2005, 19:617-619.

8. McCarthy CA, Vinh A, Callaway JK, Widdop RE: Angiotensin AT2 receptor stimulation causes neuroprotection in a conscious rat model of stroke. Stroke 2009, 40:1482-1489.
9. Mogi M, Li JM, Iwanami J, Min LJ, Tsukuda K, Iwai M, Horiuchi M: Angiotensin II type-2 receptor stimulation prevents neural damage by transcriptional activation of methyl methanesulfonate sensitive 2 . Hypertension 2006, 48:141-148.

10. Schmerbach K, Schefe JH, Krikov M, Muller S, Villringer A, Kintscher U, Unger $\mathrm{T}$, Thoene-Reineke C: Comparison between single and combined treatment with candesartan and pioglitazone following transient focal ischemia in rat brain. Brain Res 2008, 1208:225-233.

11. Gelosa P, Pignieri A, Fandriks L, de Gasparo M, Hallberg A, Banfi C, Castiglioni L, Turolo L, Guerrini U, Tremoli E, Sironi L: Stimulation of AT2 receptor exerts beneficial effects in stroke-prone rats: focus on renal damage. J Hypertens 2009, 27:2444-2451.

12. Ginsberg MD: Adventures in the pathophysiology of brain ischemia: penumbra, gene expression, neuroprotection: the 2002 Thomas Willis Lecture. Stroke 2003, 34:214-223.

13. Engelhorn T, Goerike S, Doerfler A, Okorn C, Forsting M, Heusch G, Schulz R: The angiotensin II type 1-receptor blocker candesartan increases cerebral blood flow, reduces infarct size, and improves neurologic outcome after transient cerebral ischemia in rats. J Cereb Blood Flow Metab 2004, 24:467-474.

14. Brdon J, Kaiser S, Hagemann F, Zhao Y, Culman J, Gohlke P: Comparison between early and delayed systemic treatment with candesartan of rats after ischaemic stroke. J Hypertens 2007, 25:187-196.

15. Jones ES, Vinh A, McCarthy CA, Gaspari TA, Widdop RE: AT2 receptors: functional relevance in cardiovascular disease. Pharmacol Ther 2008, 120:292-316.

16. Schrader J, Luders S, Kulschewski A, Berger J, Zidek W, Treib J, Einhaupl K, Diener HC, Dominiak P: The ACCESS Study: evaluation of Acute Candesartan Cilexetil Therapy in Stroke Survivors. Stroke 2003, 34:1699-1703.

17. Schrader J, Luders S, Kulschewski A, Hammersen F, Plate K, Berger J, Zidek W, Dominiak P, Diener HC: Morbidity and Mortality After Stroke, Eprosartan Compared with Nitrendipine for Secondary Prevention: principal results of a prospective randomized controlled study (MOSES). Stroke 2005, 36:1218-1226.

18. Unger T, Dahlof B: Compound 21, the first orally active, selective agonist of the angiotensin type 2 receptor (AT2): implications for AT2 receptor research and therapeutic potential. J Renin Angiotensin Aldosterone Syst 2010, 11:75-77.

19. Mattson MP, Barger SW, Begley JG, Mark RJ: Calcium, free radicals, and excitotoxic neuronal death in primary cell culture. Methods Cell Biol 1995, 46:187-216

20. Acker T, Acker H: Cellular oxygen sensing need in CNS function: physiological and pathological implications. J Exp Biol 2004, 207:3171-3188.

21. Martin RL, Lloyd HG, Cowan Al: The early events of oxygen and glucose deprivation: setting the scene for neuronal death? Trends Neurosci 1994, 17:251-257

22. Arumugam TV, Tang SC, Lathia JD, Cheng A, Mughal MR, Chigurupati S, Magnus T, Chan SL, Jo DG, Ouyang X, et al: Intravenous immunoglobulin (IVIG) protects the brain against experimental stroke by preventing complement-mediated neuronal cell death. Proc Natl Acad Sci U S A 2007, 104:14104-14109.

23. Brait VH, Jackman KA, Walduck AK, Selemidis S, Diep H, Mast AE, Guida E, Broughton BR, Drummond GR, Sobey CG: Mechanisms contributing to cerebral infarct size after stroke: gender, reperfusion, $\mathrm{T}$ lymphocytes, and Nox2-derived superoxide. J Cereb Blood Flow Metab 2010, 30:1306-1317.

24. Jackman KA, Miller AA, Drummond GR, Sobey CG: Importance of NOX1 for angiotensin II-induced cerebrovascular superoxide production and cortical infarct volume following ischemic stroke. Brain Res 2009, 1286:215-220

25. Bederson JB, Pitts LH, Tsuji M, Nishimura MC, Davis RL, Bartkowski H: Rat middle cerebral artery occlusion: evaluation of the model and development of a neurologic examination. Stroke 1986, 17:472-476.

26. Hattori K, Lee H, Hurn PD, Crain BJ, Traystman RJ, DeVries AC: Cognitive deficits after focal cerebral ischemia in mice. Stroke 2000, 31:1939-1944.

27. Macari D, Whitebread S, Cumin F, De Gasparo M, Levens N: Renal actions of the angiotensin AT2 receptor ligands CGP 42112 and PD 123319 after blockade of the renin-angiotensin system. Eur J Pharmacol 1994, 259:27-36. 
28. Bosnyak S, Jones ES, Christopoulos A, Aguilar MI, Thomas WG, Widdop RE: Relative affinity of angiotensin peptides and novel ligands at AT1 and AT2 receptors. Clin Sci (Lond) 2011, 121:297-303.

29. Reinecke K, Lucius R, Reinecke A, Rickert U, Herdegen T, Unger T: Angiotensin II accelerates functional recovery in the rat sciatic nerve in vivo: role of the AT2 receptor and the transcription factor NF-kappaB. FASEB J 2003, 17:2094-2096.

30. McCarthy CA, Vinh A, Callaway JK, Widdop RE: Response to Letter by Tsuda. Stroke 2009, 40:e494.

31. Zhao Y, Rempe DA: Targeting astrocytes for stroke therapy. Neurotherapeutics 2010, 7:439-451.

doi:10.1186/2040-7378-4-16

Cite this article as: Lee et al:: Neuroprotective effect of an angiotensin receptor type 2 agonist following cerebral ischemia in vitro and in vivo. Experimental \& Translational Stroke Medicine 2012 4:16.

\section{Submit your next manuscript to BioMed Central and take full advantage of:}

- Convenient online submission

- Thorough peer review

- No space constraints or color figure charges

- Immediate publication on acceptance

- Inclusion in PubMed, CAS, Scopus and Google Scholar

- Research which is freely available for redistribution 